\title{
PENGARUH KOMPETENSI SOSIAL GURU TERHADAP INTERAKSI BELAJAR MENGAJAR
}

\section{THE INFLUENCE OF TEACHER SOCIAL SKILL ON THE INTERACTION OF LEARNING TEACHING}

\author{
WN Zuliamiranti1 ${ }^{1 a}$ dan RSP Fauziah ${ }^{1}$ \\ ${ }^{1}$ Program Studi Manajemen Pendidikan Islam, Fakultas Keguruan dan Ilmu Pendidikan, \\ Universitas Djuanda Bogor, Jl. Tol Ciawi No. 1 Kotak Pos 35 Ciawi Bogor 16720 \\ a Korespondensi: Winarti Nilailasari Zuliamiranti, Email: winarti@gmail.com \\ (Diterima: 14-02-2017; Ditelaah: 14-02-2017; Disetujui: 28-04-2017)
}

\begin{abstract}
Social competence of teachers is one of the competencies that must be owned by a teacher. Social competence of teachers is the teacher's ability to interact and communicate with students, fellow teachers and the school community as well as surrounding communities. Social competence held by teachers will expedite the process of interaction and learning in the classroom. The interaction of teaching and learning is a reciprocal relationship that occurs between teachers and students in the learning process. Owned with social competence expected of a teacher is able to manage classes well in order to create a classroom atmosphere that is fun and not boring so that students feel comfortable in learning and is expected to improve the performance of students. This study aims to determine the effect of social competence of teachers to teaching and learning interactions. This study uses survey research. Mechanical analysis is regression analysis with quantitative methods, data is presented in the form of descriptive analysis. Population and sample of this study were 15 teachers. The results showed a significant correlation of social competence of teachers to teaching and learning interactions at 0.951 . Simple linear regression analysis of the social competence of teachers at 0.951 . The coefficient of $123.306 \mathrm{~F}$ and P-value $=0.000$, which is smaller than $\alpha=0.025$. It was therefore concluded there is significant influence social competence of teachers to teaching and learning interactions.
\end{abstract}

Keywords: influence, interaction, learning and teaching social, social competence, teacher.

\begin{abstract}
ABSTRAK
Kompetensi sosial guru merupakan salah satu kompetensi yang harus dimiliki oleh seorang guru. Kompetensi sosial guru merupakan kemampuan guru dalam berinteraksi dan berkomunikasi dengan murid, sesama guru dan warga sekolah serta masyarakat sekitar. Kompetensi sosial yang dimiliki guru akan memperlancar proses interaksi belajar mengajar di kelas. Interaksi belajar mengajar merupakan hubungan timbal balik yang terjadi antara guru dengan murid dalam proses belajar mengajar. Dengan kompetensi sosial yang dimiliki diharapkan seorang guru mampu mengelola kelas dengan baik agar tercipta suasana kelas yang menyenangkan dan tidak membosankan sehingga murid merasa nyaman dalam belajar dan diharapkan dapat meningkatkan prestasi murid. Penelitian ini bertujuan mengetahui pengaruh kompetensi sosial guru terhadap interaksi belajar mengajar. Penelitian ini menggunakan penelitian survey. Teknik analisisnya yaitu analisis regresi dengan metode kuantitatif, data disajikan dalam bentuk deskriptif analisis. Populasi dan sampel dari penelitian ini sebanyak 15 orang guru. Hasil penelitian menunjukkan terdapat korelasi yang signifikan kompetensi sosial guru terhadap interaksi belajar mengajar sebesar 0,951 . Analisis
\end{abstract}


regresi linier sederhana kompetensi sosial guru sebesar 0,951. Koefisien F sebesar 123,306 dan P-value $=0,000$ yang lebih kecil dari $\alpha=0,025$. Maka disimpulkan terdapat pengaruh yang signifikan kompetensi sosial guru terhadap interaksi belajar mengajar.

Kata kunci: belajar mengajar, guru, interaksi, kompetensi sosial, pengaruh.

Zuliamiranti WN dan RSP Fauziah. 2017. Pengaruh kompetensi sosial guru terhadap interaksi belajar mengajar. Tadbir Muwahhid 1(1): 81-98.

\section{PENDAHULUAN}

Guru memiliki peranan penting dalam pendidikan. Baik tidaknya guru akan mempengaruhi pendidikan terutama terhadap prestasi murid. Salah satu permasalahan yang terjadi yaitu murid merasa bosan dan jenuh belajar di kelas karena interaksi belajar mengajar di kelas yang tidak nyaman dan tidak menyenangkan yang akhirnya murid tidak suka belajar sehingga prestasinya menurun. Untuk itu seorang guru yang baik harus memiliki kompetensi agar mampu mengelola kelas dengan baik sehingga tercipta proses pembelajaran yang kondusif.

Guru yang memiliki kompetensi sosial terlihat dalam perilakunya sehari-hari terutama di sekolah. Perilaku tersebut seperti bersikap baik, sopan, santun, ramah, adil, tidak diskriminasi dan mampu menjaga hubungan baik dengan murid, teman sejawat, kepala sekolah, orang tua/wali murid, dan masyarakat sekitar. Guru yang memiliki kompetensi sosial akan dihargai oleh semua pihak karena perilakunya tersebut.

Pelaksanaan proses pembelajaran memerlukan kompetensi dari seorang guru yaitu kompetensi pedagogik, profesional, kepribadian dan kompetensi sosial. Kompetensi tersebut harus dimiliki oleh seorang guru dalam mencapai keberhasilan dalam pembelajaran. Oleh sebab itu, guru diharapkan memiliki kompetensi sebagaimana ditentukan dalam Undangundang.

Tingkat kompetensi guru secara umum masih rendah, hal ini terlihat dari hasil Uji Kompetensi Guru yang dilaksanakan oleh pemerintah pada tahun 2015, yaitu jumlah peserta Uji Kompetensi sebanyak 34 provinsi. Nilai rata-rata yang diharapkan pemerintah 53,05. Ada 10 provinsi memperoleh nilai sesuai harapan yaitu di atas rata-rata yang ditentukan. Nama provinsi tersebut yaitu: DIY $(62,36)$, Jawa Tengah $(58,93)$, DKI Jakarta $(58,36)$, Jawa Timur (56,71), Bali $(55,92)$, Jawa Barat $(55,15)$, Bangka Belitung $(55,10)$, Sumatera Barat $(54,77)$, Kepulauan Riau $(54,72)$, dan Kalimantan Selatan $(53,14)$. Sementara itu, sisanya sebanyak 24 provinsi memperoleh nilai di bawah rata-rata.

Kompetensi sosial yang dimiliki guru diperlukan dalam proses belajar mengajar. Mengajar di depan kelas merupakan perwujudan interaksi dalam proses komunikasi. Interaksi belajar mengajar akan tercipta dengan baik salah satunya apabila guru memiliki kompetensi sosial. Interaksi yang baik antara murid dan guru diharapkan mampu menciptakan suasana kelas yang nyaman dan menyenangkan bagi murid dalam belajar sehingga dapat meningkatkan prestasi belajar murid. Oleh karena itu, kompetensi sosial guru berperan penting dalam proses interaksi belajar mengajar.

Penelitian ini akan membahas tentang permasalahan yang terjadi yaitu kompetensi sosial guru di SMP Negeri 1 Gunungguruh, 
proses interaksi belajar mengajar yang terjadi di SMP Negeri 1 Gunungguruh dan pengaruh kompetensi sosial guru terhadap interaksi belajar mengajar di SMP Negeri 1 Gunungguruh Kota Sukabumi. Oleh karena itu, penelitian ini perlu dilakukan untuk menjawab permasalahan yang terjadi dengan tujuan untuk mengetahui kompetensi sosial guru, proses interaksi belajar mengajar yang terjadi dan untuk mengetahui pengaruh kompetensi sosial guru terhadap interaksi belajar mengajar di SMP Negeri 1 Gunungguruh Kota Sukabumi.

\section{MATERI DAN METODE}

\section{Materi}

\section{Kompetensi Sosial Guru}

Kompetensi guru merupakan kemampuan yang dimiliki oleh seorang guru. Kompetensi sosial merupakan salah satu kompetensi yang harus dimiliki oleh seorang guru dalam kegiatan pembelajaran. Kompetensi sosial guru adalah kemampuan sosial guru dalam berinteraksi dan berkomunikasi dengan murid secara efektif dan efisien dalam proses pembelajaran (Ashsiddiqi, 2012).

Kompetensi sosial guru ini penting untuk memperlancar komunikasi guru dengan murid baik di dalam kelas maupun di luar kelas. Setiap guru perlu mengembangkan kompetensi sosial yang dimilikinya agar dapat maksimal digunakan dalam interaksi antara guru dengan murid. Jadi dapat disimpulkan bahwa kompetensi sosial guru yaitu kemampuan sosial yang dimiliki oleh seorang guru yang harus diperhatikan agar dapat berinteraksi dan berkomunikasi dengan murid, sesama guru, kepala sekolah dan masyarakat secara efektif sehingga tujuan pembelajaran dapat tercapai dengan baik.
Karakteristik kompetensi sosial ini diuraikan lebih lanjut dalam PP RI No. 74 tahun 2008 tentang Guru sebagai bagian dari masyarakat, yang sekurang-kurangnya memiliki kompetensi untuk: berkomunikasi lisan, tulis dan/atau isyarat secara santun, menggunakan teknologi komunikasi dan informasi secara fungsional, bergaul secara efektif dengan murid, sesama pendidik, tenaga kependidikan, pimpinan satuan pendidikan, orang tua atau wali murid, bergaul secara santun dengan masyarakat sekitar dengan mengindahkan norma serta sistem nilai yang berlaku, dan menerapkan prinsip persaudaraan sejati dan semangat kebersamaan (PPRI, 2008).

\section{Interaksi Belajar Mengajar}

Proses pembelajaran tidak terlepas dari interaksi belajar mengajar yang terjadi antara guru dengan murid. Interaksi belajar mengajar ini penting dalam menciptakan suasana belajar yang nyaman dan menyenangkan. Martinis Yamin mendefinisikan tentang interaksi belajar mengajar, yaitu suatu kegiatan komunikasi yang dilakukan secara timbal balik antara murid dengan guru, mahasiswa dengan dosen dalam memahami, berdiskusi, tanya jawab, mendemonstrasi, mempraktikkan materi pelajaran di dalam kelas (Yamin, 2013). Interaksi belajar mengajar disebut juga interaksi edukatif. Interaksi ini merupakan interaksi khusus yang dilakukan di dalam kelas. Suryosubroto mengartikan interaksi edukatif adalah hubungan timbal balik antara guru dan murid dalam suatu sistem pengajaran. Interaksi edukatif merupakan faktor penting dalam usaha mencapai terwujudnya situasi belajar mengajar yang baik dalam kegiatan pendidikan dan pengajaran (Suryosubroto, 2009). 
Jadi dapat disimpulkan bahwa interaksi belajar mengajar merupakan kegiatan yang dilakukan oleh guru dan murid yang bersifat hubungan timbal balik satu sama lain dalam proses pembelajaran sehingga tercapai tujuan pembelajaran.

Menurut Roestiyah yang dikutip oleh Dian Septi Nur Afifah, interaksi yang terjadi selama pembelajaran meliputi interaksi satu arah (guru-murid), interaksi dua arah (gurumurid, murid-guru), interaksi multi arah, guru-murid, murid-guru, murid-murid. (Afifah 2012). Proses pembelajaran merupakan proses interaksi antara dua manusia, yaitu murid sebagai pihak yang belajar dengan guru sebagai pihak yang mengkondisikan terjadinya belajar. Interaksi tersebut membutuhkan komponenkomponen pendukung yang merupakan ciriciri interaksi belajar mengajar.

Menurut Martinis Yamin, ciri-ciri interaksi belajar mengajar, yaitu: ada indikator yang hendak dicapai, ada materi pokok (pesan) yang menjadi muatan interaksi, ada penjajakan kemampuan awal yang dimiliki murid, ada murid yang aktif, ada guru yang berperan sebagai fasilitator, ada sinkronisasi metode, ada situasi dan lingkungan yang mendukung sehingga terjadi proses pembelajaran, ada beberapa tagihan kompetensi terhadap hasil interaksi. (Yamin, 2013).

Tujuan proses belajar mengajar yang baik dalam pendidikan dan pengajaran akan tercapai apabila terjadi suatu usaha untuk menciptakan interaksi belajar mengajar yang baik pula antara guru yang mengajar dan murid yang belajar. Menciptakan interaksi belajar mengajar yang baik sebaiknya kita harus mengetahui komponenkomponen dasar dalam interaksi belajar mengajar. Tanpa adanya komponenkomponen tersebut tidak akan terjadi proses interaksi belajar mengajar antara guru dan murid.

Suryosubroto menyebutkan komponen interaksi belajar mengajar mencakup tujuan instruksional (tujuan instruksional ini yang pertama kali harus dirumuskan, proses interaksi ini berfungsi untuk menetapkan ke manakah tujuan pengajaran itu diarahkan), bahan pelajaran atau materi (setelah tujuan instruksional dirumuskan, harus diikuti langkah pemilihan bahan pelajaran yang sesuai dengan kondisi tingkatan murid yang akan menerima pelajaran. Jelasnya bahan pelajaran merupakan isi dari proses interaksi tersebut), metode dan alat dalam interaksi (komponen ini merupakan alat yang harus dipilih dan dipergunakan guru dalam menyampaikan bahan pelajaran (materi) dalam rangka mencapai tujuan yang telah dirumuskan. Komponen ini disebut juga metode dan alat pembantu pengajaran untuk menunjang terciptanya tujuan), sarana (interaksi hanya mungkin terjadi bila ada sarana waktu, sarana tempat, dan sarana-sarana lainnya), evaluasi atau penilaian (evaluasi ini perlu dilakukan sebab untuk melihat sejauh mana bahan yang diberikan kepada murid dengan metode tertentu dan sarana yang telah ada dapat mencapai tujuan yang telah dirumuskan. Tegasnya penilaian atau evaluasi ini merupakan barometer untuk mengukur tercapainya proses interaksi). (Suryosubroto, 2009).

Menurut Martinis Yamin, interaksi di dalam kelas bagi seorang guru sering menemui kendala yang disebabkan komunikasi yang dilakukan dari atas ke bawah atau antara guru dengan murid, komunikasi dalam koridor edukatif. Komunikasi tidak terlepas dari materi pelajaran. Artinya, interaksi yang dilakukan bersifat khusus. Di dalam kelas kemampuan pembelajar majemuk, mereka sebagian 
kreatif, sebagian statis, apatis. Sejumlah murid di dalam kelas tidak semua mereka dapat melakukan interaksi. Peran guru, dosen untuk menimbulkan minat dan motivasi bagi murid dalam berkomunikasi sangat besar. Sifat masing-masing murid tidak sama antara satu dengan lainnya, sebagian terbuka, sebagian tertutup, pemalu, berani dan sebagainya. Proses berinteraksi dalam pembelajaran mengandung pengertian memberitahukan pesan, pengetahuan, dan pikiran-pikiran dengan maksud mengikutsertakan peran murid dalam proses pembelajaran sehingga persoalan-persoalan yang dibicarakan milik bersama, dan tanggung jawab bersama. (Yamin, 2013).

Proses pembelajaran di dalamnya terjadi proses interaksi antara dua pihak. Kedudukan murid di dalam proses interaksi belajar mengajar sebagai pihak yang belajar, dan guru sebagai pihak yang mengatur terjadinya belajar. Proses interaksi belajar mengajar guru sebagai komunikator dalam menyampaikan pesan kepada murid sebagai komunikan dengan menggunakan bahasa lisan.

Bentuk-bentuk interaksi menurut Sardiman seperti dikutip oleh Dian Septi Nur Afifah berupa penjelasan, diskusi, pertanyaan dan refleksi atau persetujuan yang digunakan untuk mencapai kesepakatan dalam penyelesaian masalah (Afifah 2012).

Pola alir yang terjadi dalam suatu interaksi berkembang dari satu perseorangan kepada yang lainnya secara teratur. Analisis eksperimental pola-pola komunikasi menyatakan pengaturan tertentu mengenai "siapa berbicara kepada siapa" mempunyai konsekuensi besar berfungsi sebagai strategi pembelajaran. (Yamin, 2013)
Pola alir itu dapat saja menganut pola seperti berikut.

\section{Pola Roda}

Pola roda adalah pola interaksi yang mengarahkan seluruh informasi kepada individu yang menduduki posisi sentral. Orang yang dalam posisi sentral menerima pertanyaan, kritik, saran dari masing-masing murid lainnya, dalam hal ini dapat dilakukan dalam belajar diskusi, dan presentasi sebuah masalah. Masing-masing individu akan interaktif dengan teman lain, dengan pola yang telah dikondisikan (Yamin, 2013).

Pola roda dapat digambarkan pada Gambar 1.

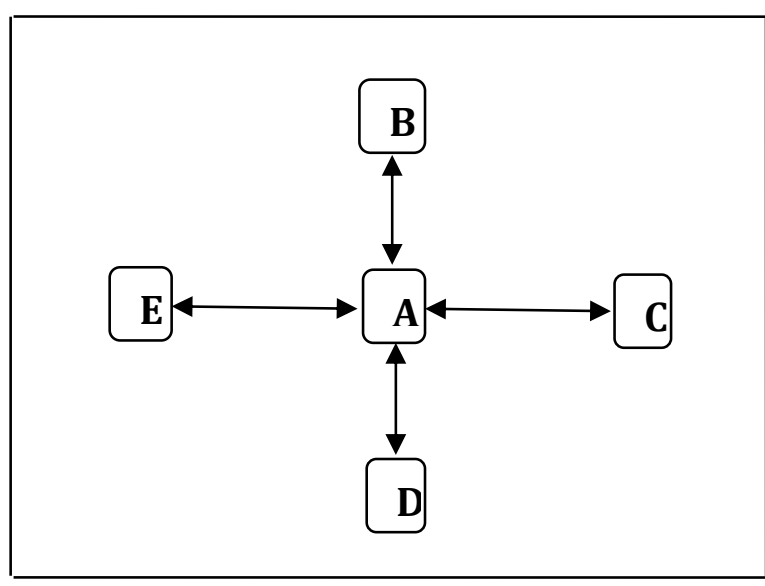

Gambar 1 Pola roda

Pola ini baik untuk kegiatan diskusi. Posisi sentral sebagai pemandu. Individu satu dengan individu yang lain tidak bisa melakukan interaksi dengan bebas tanpa dipandu oleh individu sentral.

\section{Pola lingkaran}

Pola lingkaran memungkinkan setiap murid berkomunikasi satu dengan yang lainnya melalui sejenis sistem pengulangan pesan. Tidak ada seorang anggota pun yang dapat berhubungan dengan semua anggota lainnya, demikian pula tidak ada anggota yang memiliki akses langsung terhadap seluruh informasi yang diperlukan untuk memecahkan persoalan (Yamin, 2013). 
Pola lingkaran dapat digambarkan pada gambar 2.

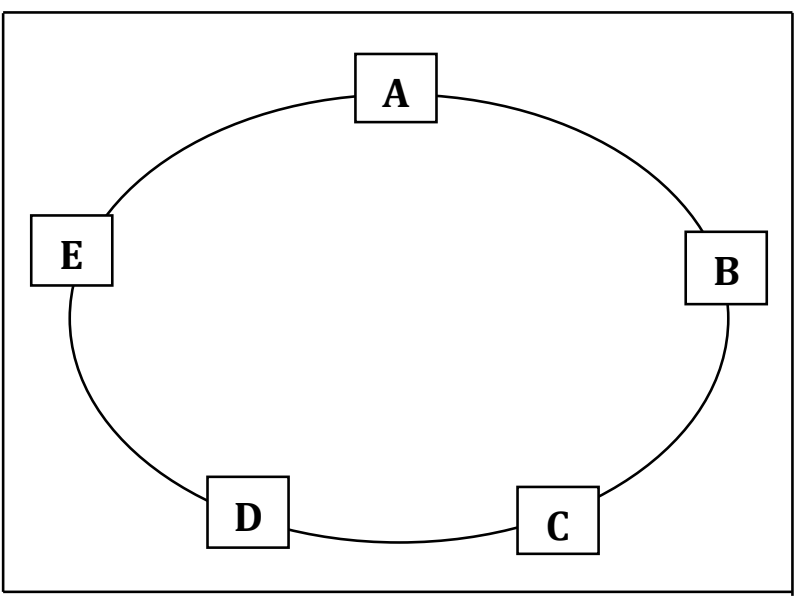

Gambar 2 Pola lingkaran

Pada pola lingkaran ini setiap individu bisa berhubungan dengan individu yang lainnya melalui pesan. Untuk informasi yang diperlukan tidak ada individu yang bisa langsung mendapatkannya.

\section{Pola alir lain}

Pola alir ini saling interaktif dengan posisi sentral. Bertindak sebagai posisi sentral adalah seseorang yang mempresentasikan masalah, yaitu A dapat berkomunikasi dengan B, C, D, E, dan F. Posisi A disini memungkinkan guru yang berkomunikasi timbal balik dengan seluruh murid (Yamin, 2013)

Pola alir lain dapat digambarkan pada gambar 3.

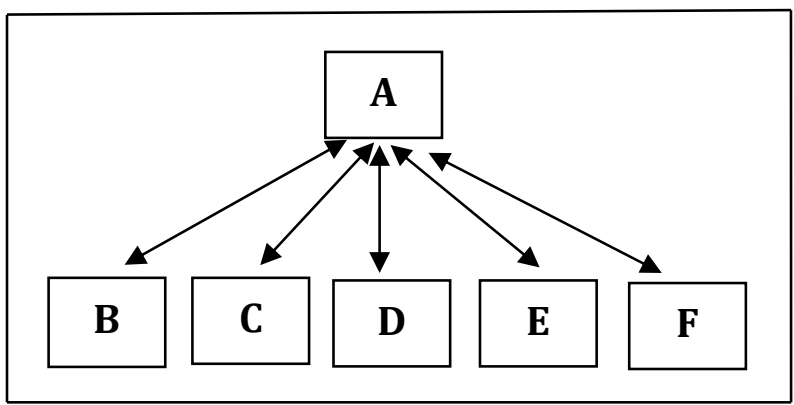

Gambar 3 Pola alir lain

Pada pola alir ini memungkinkan informasi bisa langsung diterima oleh individu di posisi sentral dan diinformasikan ke individu yang lain. Berdasarkan uraian tersebut dapat disimpulkan bahwa indikator interaksi belajar mengajar dapat dilihat dari beberapa aspek diantaranya arah interaksi, bentuk interaksi dan kepatuhan pada aturan dalam melakukan interaksi belajar mengajar.

\section{Metode}

\section{Metode Penelitian}

Desain penelitian ini menggunakan pendekatan kuantitatif. Jenis penelitian korelasi fungsional (pengaruh) yaitu penelitian yang bersifat hubungan fungsional yang bertujuan untuk mengetahui pengaruh variabel bebas terhadap variabel terikat. Teknik analisis yang digunakan dalam penelitian ini yaitu analisis regresi.

Tempat pelaksanaan yang dijadikan obyek penelitian dilakukan di SMP Negeri 1 Gunungguruh Kota Sukabumi yang beralamat di Jl. Pajajaran 1 No.20 Km.3 Kp. Gunungguruh, Desa Cikujang, Kecamatan Gunungguruh, Kota Sukabumi. Waktu penelitian untuk memperoleh data-data yang berhubungan dengan objek penelitian dilaksanakan selama 6 bulan mulai dari bulan Desember - Mei 2016 dimulai dari proses pembuatan proposal penelitian hingga laporan penelitian selesai.

Populasi adalah wilayah generalisasi berupa subjek atau objek yang mempunyai kualitas dan karakteristik tertentu yang ditetapkan oleh peneliti untuk dipelajari dan kemudian ditarik kesimpulan. Populasi dalam penelitian ini adalah guru yang ada di SMP Negeri 1 Gunungguruh Kota Sukabumi khususnya guru kelas VIII yang berjumlah 15 orang guru. Sampel adalah sebagian dari populasi yang diteliti. Dengan kata lain, sampel merupakan sebagian atau bertindak sebagai perwakilan dari populasi sehingga hasil penelitian yang berhasil diperoleh dari sampel dapat digeneralisasikan pada populasi. Maka penulis melakukan penelitian populasi, dengan jumlah populasi sebanyak 
15 orang guru. Teknik sampling yang digunakan yaitu sampel jenuh. Sampel jenuh yaitu teknik pengambilan data dengan cara mengambil semua objek populasi.

Data yang diperlukan yaitu data primer dan data sekunder. Data primer mencakup data kedua variabel yaitu data kompetensi sosial guru dan interaksi belajar mengajar. Data dikumpulkan dengan instrumen untuk kompetensi sosial guru dan interaksi belajar mengajar. Untuk data kompetensi sosial guru data diambil dengan instrumen angket, sedangkan untuk data interaksi belajar mengajar instrumen digunakan pada observasi dan pengamatan.

Sumber data kompetensi sosial guru diambil dari hasil penilaian murid kelas VIII terhadap guru kelas VIII. Berdasarkan hasil pengamatan, diambil murid kelas VIII karena kelas ini dianggap mampu untuk memberikan penilaian, karena kelas IX sudah sibuk mempersiapkan diri menghadapi Ujian Nasional dan kelas VII dianggap masih belum mampu memberikan penilaian karena baru menginjak di sekolah SMP.

Guru di kelas VIII sebanyak 15 orang dan murid kelas VIII sebanyak 240 orang. Untuk penilaian murid terhadap guru diambil sampel sebanyak 150 orang murid. Hasil penilaian murid sebanyak 150 orang untuk menilai 15 guru, setiap guru diberikan penilaian oleh 10 orang murid lalu diambil rata-rata skor penilaiannya.

Pengambilan sampel dihitung dengan menggunakan rumus sebagai berikut.

$$
\begin{aligned}
n & =\left(\frac{N}{\left(N X e^{2}\right)+1}\right) \\
& =\left(\frac{240}{\left(240 \times(0,05)^{2}\right)+1}\right) \\
& =\left(\frac{240}{1,6}\right)=150
\end{aligned}
$$

Keterangan: $n=$ banyaknya sampel; $\mathrm{N}=$ banyaknya populasi; $e=$ derajat kesalahan $=5 \%=0,05$.

\section{Teknik Pengumpulan Data}

\section{Wawancara}

Wawancara dilakukan kepada Kepala Sekolah, perwakilan guru dan perwakilan dari murid. Data sekunder yaitu data yang menunjang penelitian dalam pembuatan laporan. Data sekunder ini diambil dengan menggunakan teknik wawancara, dan dokumentasi. Wawancara dilakukan kepada Kepala Sekolah, perwakilan guru, dan perwakilan dari murid.

\section{Dokumentasi}

Dokumentasi yaitu mengumpulkan data dengan melihat atau mencatat suatu laporan yang sudah tersedia. Metode ini dilakukan dengan melihat dokumen-dokumen resmi seperti catatan-catatan dan buku-buku peraturan yang ada. Dalam penelitian ini metode dokumentasi digunakan untuk memperoleh data-data di SMP Negeri 1 Gunungguruh Kota Sukabumi khususnya guru kelas VIII yang berjumlah 15 orang guru.

\section{Teknik Analisis Data}

Data analisis deskrptif menggunakan tabel distribusi frekuensi yaitu data diurutkan dalam bentuk kelompok baris berdasarkan kelas-kelas interval. Analisis deskriptif dibutuhkan untuk menggambarkan data pengaruh kompetensi sosial guru terhadap interaksi belajar mengajar.

\section{Simple Random Sampling}

Teknik penarikan responden uji coba instrumen dengan teknik acak sederhana (Simple Random Sampling). Uji coba dilakukan di SMP Negeri 1 Gunungguruh dan diuji cobakan kepada 80 orang responden. Hasil uji validitas pada signifikansi 5\% dengan uji 2 sisi dan dicari pada $\alpha=5 \%: 2=$ 2,5\% (uji 2 sisi) dengan derajat kebebasan (df) $=n-k-1^{n}$ atau $80-1-1^{80}=78$ (n adalah 
jumlah kasus dan $\mathrm{k}$ adalah jumlah variabel independen) diketahui nilai $r$ tabel sebesar 0,22 artinya apabila nilai $r$ hitung lebih besar dari $r$ tabel maka butir soal angket dinyatakan valid dan apabila nilai $r$ hitung lebih kecil dari nilai $r$ tabel maka butir soal angket tidak valid dan harus dibuang (tidak digunakan). Uji validitas butir soal untuk variabel X menggunakan SPSS versi 16.0 dapat digambarkan dengan Tabel 1.

Tabel 1 Uji validitas variabel X

\begin{tabular}{|c|c|c|c|c|c|c|c|}
\hline No. & r hitung & $r$ tabel & Ket. & No. & r hitung & r tabel & Ket \\
\hline & $.574 "$ & & & & $.433 "$ & & \\
\hline \multirow[t]{3}{*}{1.} & .000 & 0,22 & Valid & 7. & .000 & 0,22 & Valid \\
\hline & 80 & & & & 80 & & \\
\hline & $.463 "$ & & & & $.673 "$ & & \\
\hline \multirow[t]{3}{*}{2.} & .000 & 0,22 & Valid & 8. & .000 & 0,22 & Valid \\
\hline & 80 & & & & 80 & & \\
\hline & $.556 "$ & & & & $.575^{\prime \prime}$ & & \\
\hline \multirow[t]{3}{*}{3.} & .000 & 0,22 & Valid & 9. & .000 & 0,22 & Valid \\
\hline & 80 & & & & 80 & & \\
\hline & $.641^{\prime \prime}$ & & & & $.611^{\prime \prime}$ & ר 0 & \\
\hline \multirow[t]{3}{*}{4.} & .000 & 0,22 & Valid & 10. & .000 & 0,26 & Valid \\
\hline & 80 & & & & 80 & & \\
\hline & $.308 "$ & & & & $.399 "$ & & \\
\hline \multirow[t]{3}{*}{5.} & .000 & 0,22 & Valid & 11. & .000 & 0,22 & Valid \\
\hline & 80 & & & & 80 & & \\
\hline & $.514 "$ & & & & & & \\
\hline \multirow[t]{2}{*}{6.} & .000 & 0,22 & Valid & & & & \\
\hline & 80 & & & & & & \\
\hline
\end{tabular}

Dari tabel 1 tersebut diketahui bahwa dengan pengujian 2 sisi (signifikansi $=0,025$ ) dengan hasil diperoleh untuk $r$ tabel sebesar 0,22 kemudian dibandingkan dengan nilai $r$ hitung. Dengan demikian diketahui bahwa semua nilai $r$ hitung lebih besar dari nilai $r$ tabel artinya semua item angket dinyatakan valid dan bisa dijadikan sebagai alat pengumpul data dalam penelitian yang dilakukan. Adapun hasil dari uji validitas variabel $\mathrm{X}$ adalah semua item dipakai dalam penelitian artinya tidak ada item yang dibuang dalam angket tabel 2 .
Tabel 2

\begin{tabular}{lrr}
\hline Alpha Cronbach & \multicolumn{2}{c}{ N of Item } \\
\hline & .734 & 11 \\
\hline
\end{tabular}

Adapun dari tabel 3 hasil uji reliabilitas di atas didapat nilai Alpha sebesar 0,734. Sedangkan nilai $r$ kritis (uji 2 sisi) pada signifikansi 0,05 dengan jumlah data $(n=11$ 1-1=9) didapat sebesar 0,602. Karena nilai Alpha lebih besar dari $r$ tabel yaitu 0,734 > 0,602 artinya item dalam angket dinyatakan reliabel atau terpercaya sebagai alat pengumpul data dalam penelitian. 
Validitas untuk kegiatan observasi pada variabel $\mathrm{Y}$ berkaitan dengan konsep yang digunakan untuk mendasari tujuan observasi itu sendiri. Sebelum observasi terlebih dahulu mendefinisikan konsep atau teori yang akan dipakai sebagai acuan kerangka konsepnya sehingga observasi memiliki acuan yang jelas. Hasil dari observasi dapat dijadikan referensi yang akurat untuk membuat deskripsi tentang interaksi belajar mengajar. Validitas observasi tidak dihitung secara statistik, namun cukup dengan menguraikan konsep atau teori menjadi beberapa indikator.

Tabel 3 Item total statistik

\begin{tabular}{lrrrr}
\hline & $\begin{array}{c}\text { Scale Mean if } \\
\text { Item Deleted }\end{array}$ & $\begin{array}{c}\text { Scale Variance } \\
\text { if Item Delete }\end{array}$ & $\begin{array}{c}\text { Corrected Item- } \\
\text { Total Correlation }\end{array}$ & $\begin{array}{c}\text { Cronbach's Alfa if } \\
\text { Item Delete }\end{array}$ \\
\hline Pernyataan 1 & 23.99 & 8.519 & .453 & .706 \\
Pernyataan 2 & 23.95 & 8.782 & .310 & .724 \\
Pernyataan 3 & 23.84 & 8.492 & .422 & .709 \\
Pernyataan 4 & 24.29 & 8.106 & .516 & .695 \\
Pernyataan 5 & 24.35 & 9.370 & .155 & .743 \\
Pernyataan 6 & 24.38 & 8.592 & .368 & .717 \\
Pernyataan 7 & 23.85 & 8.900 & .296 & .726 \\
Pernyataan 8 & 24.29 & 7.575 & .520 & .692 \\
Pernyataan 9 & 23.76 & 8.310 & .432 & .707 \\
Pernyataan 10 & 23.71 & 8.233 & .480 & .700 \\
Pernyataan 11 & 24.22 & 9.291 & .195 & .737 \\
\hline
\end{tabular}

Mencari reliabilitas dalam kegiatan observasi itu perlu, dimana reliabilitas observasi adalah keajegan apa yang diobservasi. Agar suatu pengukuran observasi dapat dipercaya, maka idealnya hasil observasi bila diuji kembali oleh orang lain baik di lain waktu maupun sekarang maka hasilnya relatif sama.

Tabel 4 Skor pernyataan pada lembar observasi

\begin{tabular}{lc}
\hline \multicolumn{1}{c}{ Kategori } & Skor \\
\hline Baik & 3 \\
Cukup & 2 \\
Kurang & 1 \\
\hline
\end{tabular}

Validitas observasi tidak dihitung secara statistik, namun cukup dengan menguraikan konsep atau teori menjadi beberapa indikator. Adapun uraiannya adalah sebagai berikut.

a. Konsep: Interaksi belajar mengajar merupakan kegiatan yang dilakukan oleh guru dan murid yang bersifat hubungan timbal balik satu sama lain dalam proses pembelajaran sehingga tercapai tujuan pembelajaran.

b. Aspek: Dalam interaksi belajar mengajar ada beberapa aspek yang terdiri dari aspek arah dan bentuk dan aspek kepatuhan pada aturan. Aspek arah dan bentuk berupa pertanyaan, penjelasan, diskusi dan kesepakatan hasil diskusi. Aspek kepatuhan pada aturan berupa norma yang harus dipatuhi dalam melakukan interaksi belajar mengajar. 
c. Indikator: Adapun indikator interaksi belajar mengajar adalah sebagai berikut.

1) Arah dan Bentuk Interaksi

a) Guru mengucapkan salam saat memulai pelajaran

b) Guru mengajar diselingi candaan agar tidak membosankan

c) Guru menjelaskan materi pelajaran dengan mudah dimengerti

d) Guru bertanya kepada murid tentang materi pelajaran

e) Guru memotivasi murid untuk rajin belajar

f) Guru menjawab pertanyaan murid dengan ramah

g) Murid memperhatikan penjelasan guru

h) Murid bertanya tentang materi pelajaran

i) Murid antusias dalam belajar dan belajar dengan menyenangkan

j) Murid melakukan diskusi dengan teman sekelas

k) Murid dengan murid melakukan refleksi atau kesepakatan

2) Kepatuhan pada aturan

a) Guru menyampaikan materi dengan tutur kata yang sopan

b) Guru berpenampilan yang baik dan sopan

c) Guru tidak mudah menyalahkan saat murid kurang tepat dalam menjawab pertanyaan

d) Guru mempersilahkan murid untuk bertanya

e) Murid menjawab pertanyaan setelah diberi kesempatan
Untuk instrumen observasi tidak dilakukan uji validitas dan reliabilitas karena jawaban yang didapatkan sesuai dengan fakta yang ada di lapangan. Deskripsi data adalah deskripsi yang menggambarkan karakteristik atau sekelompok data yang menggunakan teknik statistik deskriptif. Deskripsi data pada penelitian ini diambil dari hasil pengukuran dan wawancara. Dari wawancara dilakukan dengan kepala sekolah, perwakilan guru dan perwakilan dari murid.

Analisis data penelitian ini adalah untuk melakukan perhitungan dalam rangka menjawab rumusan yang telah diajukan. Dalam teknik analisis di sini digunakan teknik regresi. Analisis regresi ini untuk mengetahui bagaimana pola variabel dependent (kriteria) dapat diprediksikan melalui variabel independent (prediktor). Rumus persamaan regresi sebagai berikut.

$$
\hat{\mathrm{Y}}=\mathrm{a}+\mathrm{bX}
$$

Keterangan: $\hat{Y}=$ Variabel dependent (nilai yang diprediksikan); X = Variabel Independent (prediktor); $\mathrm{a}=$ Konstanta (harga $\mathrm{Y}$ untuk $\mathrm{X}=0$ ); $\mathrm{b}=$ angka arah (koefisien regresi), bila b positif (+) arah regresi naik, dan bila $b$ negatif $(-)$ arah regresi turun.

Harga a dan b dapat ditentukan dengan rumus sebagai berikut.

$$
\begin{aligned}
b & =\frac{\mathrm{n} \Sigma \mathrm{xy}-\Sigma \mathrm{x} \Sigma \mathrm{y}}{n \Sigma x^{2}-(\Sigma \mathrm{x})^{2}} \\
a & =\frac{\sum \mathrm{y} \Sigma \mathrm{x}^{2}-\Sigma \mathrm{x} y}{n \Sigma \mathrm{x}^{2}-(\Sigma \mathrm{x})^{2}}
\end{aligned}
$$

Hipotesis Statistika dapat ditulis sebagai berikut.

$$
\mathrm{H}_{0}: \beta=0 \quad \mathrm{H}_{1}: \beta \neq 0
$$

Keterangan: $\mathrm{H}_{0}=$ Tidak ada pengaruh kompetensi sosial guru terhadap interaksi belajar mengajar; $\mathrm{H}_{1}=$ Ada pengaruh kompetensi sosial guru terhadap interaksi belajar mengajar. 


\section{HASIL DAN PEMBAHASAN}

\section{Hasil}

Berangkat dari sebuah keinginan masyarakat Kecamatan Cisaat untuk memiliki Sekolah Menengah Pertama berstatus Negeri maka dibentuklah panitia persiapan pembangunan SLTP Negeri 2 Cisaat. Pada awalnya, pembelajaran dilaksanakan di SD Negeri 1 Kutamaneuh yaitu tahun 1982. Pada awal tahun 1983 pelaksanaan pembelajaran di pindah ke SLTP Negeri 1 Cisaat. Hal ini dilakukan karena pembangunan gedung sekolah belum selesai. Pada tanggal 1 Juli 1983, sekolah sudah didirikan dan kegiatan belajar mengajar mulai dilaksanakan di gedung SLTP Negeri 2 Cisaat di Jl. Pajajaran 1 No. 20 Km 3 Gunungguruh. Sehubungan dengan adanya pemekaran wilayah Kecamatan maka pada tanggal 30 April 2003, pemerintah merubah nama sekolah SLTP Negeri 2 Cisaat menjadi SMP Negeri 1 Gunungguruh (Gunungguruh merupakan kecamatan baru sebagai pemekaran dari Kecamatan Cisaat). Waktu penelitian ini dilakukan nama sekolah ini sudah menjadi SMP Negeri 1 Gunungguruh.

Visi SMP Negeri 1 Gunungguruh adalah "Terwujudnya murid yang cerdas spiritual, emosional, dan intelektual serta mengedepankan kearifan lokal".

Untuk mewujudkan visi tersebut maka SMP Negeri 1 Gunungguruh merumuskan misi sebagai berikut.

1) Mewujudkan warga sekolah yang memiliki akidah yang lurus dan bersih.

2) Mewujudkan warga sekolah yang taat beribadah.

3) Membiasakan budaya $3 \mathrm{~S}$ (Senyum, salam dan sapa) antar warga sekolah.

4) Mewujudkan warga sekolah yang pandai berterima kasih dan meminta maaf.
5) Membiasakan warga sekolah untuk selalu bersikap jujur dalam setiap kegiatan.

6) Mewujudkan warga sekolah yang sopan dan santun dalam berbicara dan bersikap.

7) Mewujudkan warga sekolah yang gemar membaca.

8) Membiasakan warga sekolah untuk berbahasa sunda yang baik dan benar.

9) Mewujudkan warga sekolah yang cinta dengan budaya sunda.

10)Mewujudkan warga sekolah yang cinta kebersihan dan keindahan, serta memiliki sikap peduli lingkungan.

Tujuan Sekolah SMP Negeri 1 Gunungguruh yaitu "Terwujudnya warga sekolah yang memiliki akidah yang lurus dan bersih, yang taat beribadah, yang senantiasa selalu tersenyum, mengucap salam, dan menyapa dengan ramah antar warga sekolah, pandai berterima kasih dan meminta maaf, selalu bersikap jujur dalam setiap kegiatan, sopan dan santun dalam berbicara dan bersikap, gemar membaca, berbahasa sunda yang baik dan benar, cinta dengan budaya sunda, dan cinta kebersihan dan keindahan, serta memiliki sikap peduli lingkungan.

Ekstrakurikuler di SMP Negeri 1 Gunungguruh ialah Ekstrakurikuler Keagamaan (Remaja Mesjid, Qasidah), Drumband (Gitaloka Persada), Paskibra, Pramuka, Palang Merah Remaja (PMR), Karate, Ekstrakurikuler Olahraga (Volly, Basket, Futsal), Paduan Suara (Padus), English Club, dan Seni Tari.

Guru di SMP Negeri 1 Gunungguruh ini beragam ada guru tetap dengan status PNS, guru honor dan guru pindahan. Guru-guru di sekolah ini kebanyakan sudah PNS dan merupakan guru senior yang sudah mengabdi di sekolah ini sejak lama bahkan 
ada beberapa orang guru yang mengabdi sejak sekolah ini belum berdiri masih menumpang di sekolah lain.

Murid di SMP Negeri 1 Gunungguruh juga beragam ada yang jarak tempat tinggalnya jauh ada yang dekat. Kebanyakan murid di sekolah ini merupakan warga di sekitar lokasi sekolah yang rata-rata berekonomi menengah ke bawah. Walaupun tinggal di daerah pedesaan namun semangat belajar murid-murid di sekolah ini sangat baik, hal ini terlihat dari berbagai prestasi yang telah mereka raih. Murid di sekolah ini berprestasi dalam bidang yang beragam tidak hanya berprestasi di bidang akademik tapi juga di bidang yang lain seperti olah raga, seni dan beladiri.

\section{Deskripsi Data Kompetensi Sosial Guru (Variabel X)}

Data hasil penelitian tentang kompetensi sosial guru melalui instrumen angket dengan jumlah responden sebanyak 15 orang guru, diketahui bahwa skor kompetensi sosial guru tertinggi sebesar 85 , skor terendah 72 , dan rerata 79,07. Berdasarkan hasil pengolahan data diperoleh standar deviasi
3,390. Data skor kompetensi sosial guru (Variabel X) dapat digambarkan pada tabel 5.

Tabel 5 Skor variabel $\mathrm{X}$

\begin{tabular}{clr}
\hline No. & \multicolumn{1}{c}{ Nama Guru } & Skor \\
\hline 1. & Ramlan Slamet, S.Pd. & 77 \\
2. & M. Alfatih, S.Pd. & 74 \\
3. & Mutia Puji A, S.Pd. & 77 \\
4. & Atang Sopandi, S.Pd. & 72 \\
5. & Ida Nurfaidha, S.Pd. & 77 \\
6. & Dra. Tati & 81 \\
7. & Rd. Muhtar Sjahroni, S.Pd. & 79 \\
8. & Dasita Kartawijaya, S.Pd. & 85 \\
9. $\quad$ Sudayat, S.Pd. & 83 \\
10. & Ahmad, S.Pd. & 80 \\
11. Ida Agustina, S.Pd. & 81 \\
12. & Ekasari, S.Pd. & 78 \\
13. $\quad$ Hilman Indra L., S.Pd. & 82 \\
14. & Tatang, S.Pd. & 79 \\
15. & Rika Kartikasari, S.Pd & 81 \\
Tertinggi & 85 \\
Terendah & 72 \\
Rata-rata & 79,07 \\
\hline
\end{tabular}

Data kompetensi sosial guru dalam distribusi frekuensi dapat digambarkan pada tabel 6 .

Tabel 6 Distribusi frekuensi data variabel X

\begin{tabular}{lcrrr}
\hline \multicolumn{1}{c}{ Tingkat } & Interval Nilai & \multicolumn{1}{c}{ Frekuensi } & Persen & Persentase Kumulatif \\
\hline Tinggi & $81-85$ & 6 & 40 & 40 \\
Sedang & $76-80$ & 7 & 47 & 87 \\
Rendah & $71-75$ & 2 & 13 & 100 \\
Total & & 15 & 100 & \\
\hline
\end{tabular}

Dari tabel distribusi tersebut (Tabel 6) diketahui bahwa guru yang memiliki kompetensi sosial tinggi sebanyak 6 orang, kompetensi sosial sedang sebanyak 7 orang dan kompetensi sosial rendah sebanyak 2 orang. Data pada tabel 6 dapat digambarkan dalam bentuk grafik 1 .
Selain dari hasil pengukuran, data juga diambil dari hasil wawancara dan pengamatan. Dari hasil wawancara dengan kepala sekolah diketahui bahwa rata-rata guru di sekolah ini memiliki kompetensi sosial yang baik. Kepala sekolah juga mengemukakan bahwa dari hasil UKG yang 
diikuti oleh guru diketahui hasilnya baik bahkan memuaskan dengan perolehan skor diatas rata-rata yang diinginkan yaitu sebesar 55,15. Hal ini membuktikan bahwa kompetensi sosial yang dimiliki oleh guru di SMP Negeri 1 Gunungguruh sudah baik.

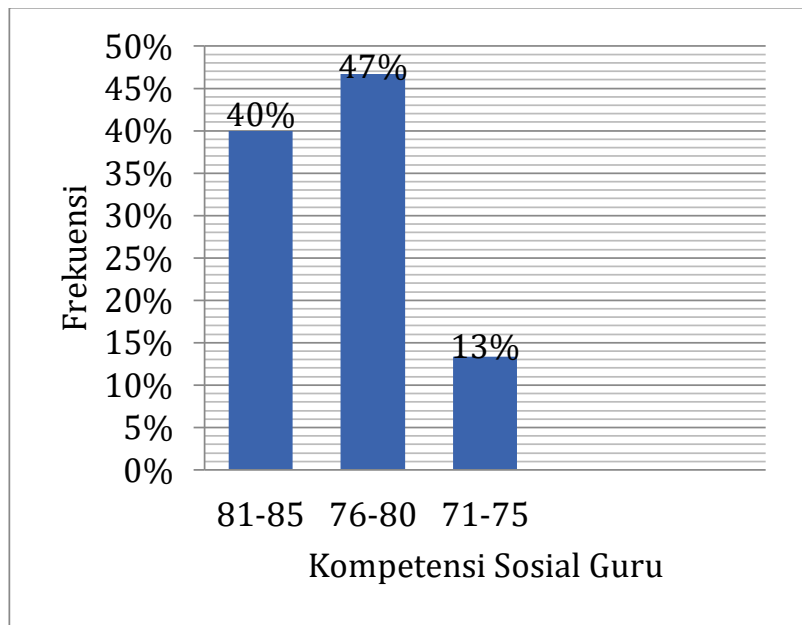

Grafik 1 Histogram variabel X

Berdasarkan pengamatan peneliti diketahui bahwa guru-guru di SMP Negeri 1 Gunungguruh memiliki kompetensi sosial yang baik terlihat dari keseharian di sekolah. Guru-guru di sekolah ini ramah, sopan, murah senyum, selalu menegur setiap berpapasan dengan siapa pun itu baik warga sekolah sendiri maupun dengan tamu. Seluruh guru melaksanakan $3 \mathrm{~S}$ yaitu Senyum, Salam dan Sapa. Hal ini membuat suasana di sekolah penuh dengan keakraban.

\section{Deskripsi Data Interaksi Belajar Mengajar (Variabel Y)}

Data hasil pengukuran tentang interaksi belajar mengajar melalui observasi dengan jumlah responden sebanyak 15 orang guru, diketahui bahwa skor tertinggi sebesar 80, skor terendah 68, dan skor rerata 73,93. Berdasarkan hasil pengolahan data, diperoleh standar deviasi 3,390. Data skor interaksi belajar mengajar (Variabel Y) digambarkan pada tabel 7 .

Tabel 7 Data skor variabel Y

\begin{tabular}{lll}
\hline No. & \multicolumn{1}{c}{ Nama Guru } & Skor \\
\hline 1. & Ramlan Slamet, S.Pd. & 72 \\
2. & M. Alfatih, S.Pd. & 70 \\
3. $\quad$ Mutia Puji A, S.Pd. & 71 \\
4. $\quad$ Atang Sopandi, S.Pd. & 68 \\
5. $\quad$ Ida Nurfaidha, S.Pd. & 70 \\
6. $\quad$ Dra. Tati & 76 \\
7. $\quad$ Rd. Muhtar Sjahroni, S.Pd. & 75 \\
8. $\quad$ Dasita Kartawijaya, S.Pd. & 80 \\
9. $\quad$ Sudayat, S.Pd. & 78 \\
10. $\quad$ Ahmad, S.Pd. & 75 \\
11. $\quad$ Ida Agustina, S.Pd. & 74 \\
12. $\quad$ Ekasari, S.Pd. & 72 \\
13. $\quad$ Hilman Indra L, S.Pd. & 78 \\
14. $\quad$ Tatang, S.Pd. & 75 \\
15. $\quad$ Rika Kartikasari, S.Pd. & 75 \\
Tertinggi & 80 \\
Terendah & 68 \\
Rata-rata & 73,93 \\
\hline
\end{tabular}

Distribusi data interaksi belajar mengajar berdasarkan tabel distribusi frekuensi dapat disajikan pada tabel 8.

Tabel 8 Distribusi frekuensi data variabel Y

\begin{tabular}{lcrrr}
\hline \multicolumn{1}{c}{ Tingkat } & Interval Nilai & Frekuensi & Persen & Persentase Kumulatif \\
\hline Tinggi & $76-80$ & 4 & 27 & 27 \\
Sedang & $71-75$ & 8 & 53 & 80 \\
Rendah & $66-70$ & 3 & 20 & 100 \\
Total & & 15 & 100 & \\
\hline
\end{tabular}


Dari tabel 8 (delapan) diketahui bahwa guru yang melakukan interaksi belajar mengajar tingkat tinggi sebanyak 4 orang, tingkat sedang sebanyak 8 orang dan tingkat rendah sebanyak 3 orang. Dengan demikian kebanyakan guru di SMP Negeri 1 Gunungguruh Sukabumi melakukan interaksi belajar mengajar pada tingkat sedang.

Data di atas dapat digambarkan dalam bentuk grafik 2 .

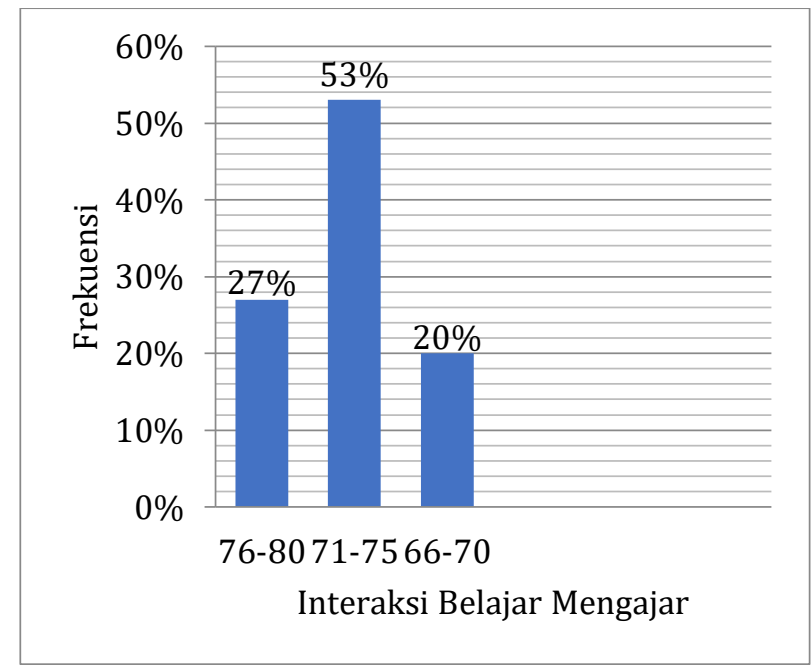

Grafik 2 Histogram variabel Y

Selain data hasil pengukuran dari observasi, data untuk interaksi belajar mengajar juga diambil dari hasil wawancara dengan beberapa orang murid. Dari hasil wawancara diketahui bahwa interaksi belajar mengajar di SMP Negeri 1 Gunungguruh baik. Mereka mengemukakan bahwa mereka belajar dengan suasana yang menyenangkan dan tidak membosankan.

\section{Hasil Penelitian Hipotesis}

Hipotesis yang akan diuji pada penelitian ini yaitu:

H0 : Tidak ada pengaruh kompetensi sosial guru terhadap interaksi belajar mengajar.

H1 : Ada pengaruh kompetensi sosial guru terhadap interaksi belajar mengajar.
Berikut deskriptif data tentang kompetensi sosial guru dan interaksi belajar mengajar pada tabel 9 .

Tabel 9 Data skor variabel X dan variabel Y

No. Nama Guru Variabel Variabel

\begin{tabular}{llcr} 
& & X & \multicolumn{1}{c}{ Y } \\
\hline 1. & Ramlan & 77 & 72 \\
& Slamet, S.Pd. & &
\end{tabular}

$\begin{array}{llll}\text { 2. M. Alfatih, } & 74 & 70\end{array}$

S.Pd.

3. Mutia Puji A, $\quad 77 \quad 71$

S.Pd.

$\begin{array}{llll}\text { 4. } & \text { Atang } & 72 & 68\end{array}$

Sopandi,

S.Pd.

$\begin{array}{llll}\text { 5. Ida } & 77 & 70\end{array}$

Nurfaidha,

S.Pd.

6. Dra. Tati $\quad 81 \quad 76$

7. Rd. Muhtar $79 \quad 75$

Sjahroni,

S.Pd.

8. Dasita $\quad 85 \quad 80$

Kartawijaya,

S.Pd.

9. Sudayat, S.Pd. $\quad 83 \quad 78$

10. Ahmad, S.Pd. $80 \quad 75$

11. Ida Agustina, $\quad 81 \quad 74$

S.Pd.

12. Ekasari, S.Pd. 78

13. Hilman Indra $82 \quad 78$

L., S.Pd.

14. Tatang, S.Pd. 79

$\begin{array}{lll}\text { 15. Rika } & 81 & 75\end{array}$

Kartikasari,

S.Pd

Adapun pada tabel 10, rerata pada variabel kompetensi sosial guru 79,07 dan standar deviasi 3,390 sedangkan rerata pada 
variabel interaksi belajar mengajar 73,93 dan standar deviasi 3,390.

Tabel 10 Deskriptif data

\begin{tabular}{llll}
\hline & $\begin{array}{l}\text { Rata- } \\
\text { rata }\end{array}$ & $\begin{array}{l}\text { Std. } \\
\text { Deviasi }\end{array}$ & $\mathrm{N}$ \\
\hline $\begin{array}{l}\text { Kompetensi } \\
\text { Sosial Guru }\end{array}$ & 79.07 & 3.390 & 15 \\
$\begin{array}{l}\text { Interaksi } \\
\text { Belajar }\end{array}$ & 73.93 & 3.390 & 15 \\
Mengajar & & & \\
\hline
\end{tabular}

Jika dilihat korelasi yang signifikan antara variabel kompetensi sosial guru (X) dengan variabel interaksi belajar mengajar (Y) dengan uji korelasi product moment menggunakan SPSS 16.0, antara variabel X dengan variabel $Y$ diperoleh indeks korelasi sebesar 0,951 .

Di bawah ini hasil perhitungan SPSS 16.0, uji korelasi antara kompetensi sosial guru (X) dengan interaksi belajar mengajar (Y) pada tabel 11 .

Tabel 11 Korelasi variabel X dan variabel Y

\begin{tabular}{|c|c|c|c|c|}
\hline & & & $\begin{array}{l}\text { Kompetensi Sosial } \\
\text { Guru }\end{array}$ & $\begin{array}{c}\text { Interaksi Belajar } \\
\text { Mengajar }\end{array}$ \\
\hline \multirow{3}{*}{$\begin{array}{l}\text { Kompetensi } \\
\text { guru }\end{array}$} & sosial & Pearson Correlation & 1 & $.951 "$ \\
\hline & & Sig. (2-tailed) & & .000 \\
\hline & & $\mathrm{N}$ & 15 & 15 \\
\hline \multirow{3}{*}{$\begin{array}{l}\text { Interaksi } \\
\text { mengajar }\end{array}$} & belajar & Pearson Correlation & $.951 "$ & 1 \\
\hline & & Sig. (2-tailed) & .000 & \\
\hline & & $\mathrm{N}$ & 15 & 15 \\
\hline
\end{tabular}

Pengujian koefisien regresi a dan $b$ dari persamaan regresi linear sederhana $\hat{Y}=a+$ bX dengan bentuk hipotesis $\mathrm{H}_{\mathrm{o}}: \beta=0$ dan $\mathrm{H}_{1}$ : $\beta \neq 0$. Berdasarkan hasil perhitungan pada tabel ringkasan singkat, diperoleh nilai $\mathrm{R}$ square 0,905 (90,5\%). Hal ini berarti indeks korelasi antar variabel bebas (X) terhadap variabel terikat (Y) sebesar 90,5\% sedangkan sisanya merupakan indeks korelasi dari variabel lain seperti yang terdapat dalam Tabel 12.

Tabel 12 Ringkasan singkat

\begin{tabular}{|l|l|l|l|l|}
\hline Model & $\mathrm{R}$ & R Square & Adjusted R Square & Std. Error of the Estimate \\
\hline 1 & $.951^{\mathrm{a}}$ & .905 & .897 & 1.087 \\
\hline
\end{tabular}

Keterangan: a. Predictors : (Constant), Kompetensi Sosial Guru; b. Dependent Variable : Interaksi Belajar Mengajar.

Persamaan garis regresi yang diperoleh yaitu $\hat{Y}=-1,268+0,951 X$. Dari persamaan tersebut mengandung arti bahwa:

a. Konstanta sebesar -1,268 menyatakan bahwa kalau nilai b 0 (koefisien arah regresi) maka nilai interaksi sebesar 1,268 . Konstanta negatif $(-1,268)$ artinya ada pengaruh negatif dari variabel lain selain kompetensi sosial guru terhadap interaksi belajar mengajar.

b. Koefisien regresi $X$ sebesar 0,951 menyatakan bahwa setiap penambahan 1 nilai b maka nilai partisipasi bertambah sebesar 0,951. Berikut hasil perhitungan persamaan garis regresi tabel 13. 
Tabel 13 Koefisien

\begin{tabular}{lrrrrrr}
\hline \multirow{2}{*}{ Model } & \multicolumn{2}{c}{$\begin{array}{c}\text { Unstandardized } \\
\text { Coefficient }\end{array}$} & \multicolumn{2}{c}{$\begin{array}{c}\text { Standardized } \\
\text { Coefficients }\end{array}$} & \multirow{2}{*}{ S } & Sig. \\
\cline { 2 - 5 } & \multicolumn{1}{c}{ B } & Std. Error & Beta & & \\
\hline 1 (Constant) & -1.268 & 6.778 & & & -.187 & .854 \\
Kompetensi Sosial Guru & .951 & .086 & .951 & 11.104 & .000 \\
\hline
\end{tabular}

Dari output pada tabel di atas diketahui nilai thitung 11,104 dengan nilai signifikansi $0,000<0,05$, maka H0 ditolak dan H1 diterima. Hal ini berarti ada pengaruh yang nyata (signifikan) antara kompetensi sosial guru terhadap interaksi belajar mengajar.

Dari tabel ANOVA diperoleh nilai $\mathrm{F}$ sebesar 123,306 dengan signifikansi 0,000 pada $\alpha=0,05$, karena nilai signifikansi lebih kecil dari alpha $(0,000<0,05)$ artinya ada pengaruh yang signifikan variabel $X$ (kompetensi sosial guru) terhadap variabel Y (interaksi belajar mengajar) maka model regresi dapat dipakai untuk memprediksi variabel partisipasi (variabel Y) seperti pada tabel 14 .

Tabel 14 ANOVA

\begin{tabular}{lllllll}
\hline & Model & \multicolumn{1}{c}{$\begin{array}{c}\text { Sum of } \\
\text { Squares }\end{array}$} & Df & Mean Square & F & Sig. \\
\hline 1 & Regression & 145.585 & 1 & 145.585 & 123.306 & $.000^{\text {a }}$ \\
& Residual & 15.349 & 13 & 1.181 & & \\
& Total & 160.933 & 14 & & & \\
\hline
\end{tabular}

Keterangan: a. Predictors : (Constant), Kompetensi Sosial Guru; b. Dependent Variable : Interaksi Belajar Mengajar.

Uji prasyarat analisis data pada penelitian ini adalah uji linearitas. Uji linearitas dilakukan dengan mencari persamaan regresi variabel X dengan Variabel Y dengan

Tabel 15 Uji Linieritas taraf signifikansi $5 \%(0,05)$. Dengan uji linearitas sudah menunjukan data berdistribusi normal atau tidak.

\begin{tabular}{lllrrrrr}
\hline & & & $\begin{array}{l}\text { Sum Of } \\
\text { Squares }\end{array}$ & df & \multicolumn{1}{c}{$\begin{array}{c}\text { Mean } \\
\text { Square }\end{array}$} & F & Sig. \\
\hline Interaksi & Between & (Combined) & 156.933 & 9 & 17.437 & 21.796 & .002 \\
Belajar & Groups & $\begin{array}{l}\text { Linearity } \\
\text { Deviation }\end{array}$ & 145.585 & 1 & 145.585 & 181.981 & .000 \\
Mengajar & & 11.349 & 8 & 1.419 & 1.773 & .274 \\
Kompetensi & & from & & & & & \\
Sosial Guru & Within & Linearity & 4.000 & 5 & .800 & & \\
& Groups & & 160.933 & 14 & & & \\
& Total & & & & & & \\
& & & & & & &
\end{tabular}


Berdasarkan tabel uji linearitas, diketahui bahwa nilai signifikasi sebesar 0,274 lebih besar dari 0,05 yang artinya terdapat hubungan linear secara signifikan antara variabel kompetensi sosial guru (Variabel X) dengan variabel interaksi belajar mengajar (Variabel Y), sehingga dapat disimpulkan bahwa data yang diuji linier (searah). Adapun hasil uji linearitas dapat dilihat pada tabel 15.

\section{Pembahasan}

\section{Kompetensi Sosial Guru}

Hasil penelitian tentang kompetensi sosial guru yang datanya diambil dengan instrumen angket diketahui bahwa kompetensi sosial guru di SMP Negeri 1 Gunungguruh baik dengan rata-rata skor yang diperoleh sebesar 79,07. Hasil wawancara dengan kepala sekolah SMP Negeri 1 Gunungguruh dan hasil pengamatan peneliti sendiri selama penelitian diketahui bahwa kompetensi sosial guru SMP Negeri 1 Gunungguruh sangat baik bahkan tidak hanya guru yang mengembangkan kompetensi sosial tetapi seluruh murid juga dianjurkan untuk mengembangkan kompetensi sosialnya hal ini terlihat dari Visi dan Misi sekolah yang mengharuskan murid untuk melaksanakan 3 S yaitu senyum, salam sapa. Dari hasil UKG, wawancara dan pengamatan bahwa kompetensi sosial guru di SMP Negeri 1 Gunungguruh sangat baik sehingga semua guru ramah dan tercipta keharmonisan antara seluruh warga sekolah.

\section{Interaksi Belajar Mengajar}

Hasil dari penelitian dengan instrumen angket diketahui bahwa interaksi belajar mengajar di SMP Negeri 1 Gunungguruh sudah baik dengan skor rata-rata yang diperoleh sebesar 73,93. Peneliti juga melihat sendiri proses interaksi yang terjadi di dalam kelas. Tercipta suasana yang menyenangkan dan kelas menjadi kondusif sehingga murid antusias untuk belajar.

\section{Pengaruh Kompetensi Sosial Guru terhadap Interaksi Belajar Mengajar}

Kriteria penerimaan atau penolakan tingkat signifikansi ( $P$-Value) yang dipakai untuk pengujian hipotesis pada uji korelasi yaitu: jika $\mathrm{P}$-value $<\alpha$, maka $\mathrm{H}_{0}$ ditolak; dan jika $\mathrm{P}$ value $>\alpha$, maka $\mathrm{H}_{0}$ diterima.

Hasil perhitungan diperoleh indeks korelasi 0,951 dengan nilai signifikan 0,000. Dengan demikian karena signifikansi 0,000 lebih kecil dari $\alpha=0,025$ (uji dua sisi), maka $\mathrm{H}_{0}$ ditolak dan $\mathrm{H}_{1}$ diterima. Hal ini berarti ada hubungan yang signifikan antara kompetensi sosial guru dengan interaksi belajar mengajar di SMP Negeri 1 Gunungguruh.

Bentuk persamaan regresi linear sederhana diperoleh $\hat{Y}=-1,268+0,951 X$ hal ini berarti jika tidak ada nilai b (variabel $\mathrm{X}$ ) maka nilai variabel Y sebesar -1,268 artinya nilai untuk variabel $\mathrm{Y}$ kecil dan banyak dipengaruhi oleh nilai variabel $\mathrm{X}$, dengan demikian variabel $Y$ (interaksi belajar mengajar) sangat bergantung kepada variabel X (kompetensi sosial guru). Berdasarkan nilai $\mathrm{R}$ Square, persamaan regresi dapat dijelaskan bahwa 90,5\% dari variansi interaksi belajar mengajar dapat dijelaskan oleh kompetensi sosial guru.

Regresi (hubungan fungsional) kompetensi sosial guru dengan interaksi belajar mengajar secara statistik dengan nilai $\mathrm{F}=123,306$ dengan signifikan pada derajat kebebasan $(\mathrm{k}=1)$ dan $\mathrm{n}-\mathrm{k}-1=15-1$ - $1=13$, serta P-value $=0,000$ yang lebih kecil dari $\alpha=0,025$. Dengan demikian uji hipotesis $\mathrm{H}_{0}: \beta=0$ terhadap $\mathrm{H}_{0}: \beta \neq 0$ berdasarkan tabel ANOVA diperoleh $\mathrm{H}_{0}$ ditolak karena P-value $<\alpha=0,000<0,025$. Artinya, ada pengaruh yang signifikan 
kompetensi sosial guru terhadap interaksi belajar mengajar.

\section{KESIMPULAN DAN IMPLIKASI}

\section{Kesimpulan}

1. Kompetensi sosial guru di SMP Negeri 1 Gunungguruh kota Sukabumi sangat baik, hal ini ditunjukkan dengan skor rerata variabel $\mathrm{X}$ (kompetensi sosial guru) sebesar 79.07. Hasil wawancara dengan kepala sekolah SMP Negeri 1 Gunungguruh dan hasil pengamatan peneliti sendiri selama penelitian diketahui bahwa kompetensi sosial guru SMP Negeri 1 Gunungguruh sangat baik.

2. Interaksi belajar mengajar di SMP Negeri 1 Gunungguruh kota Sukabumi berjalan dengan baik, hal ini ditunjukkan dengan skor rerata variabel Y (interaksi belajar mengajar) sebesar 73,93. Peneliti juga melihat sendiri proses interaksi yang terjadi di dalam kelas. Tercipta suasana yang menyenangkan dan kelas menjadi kondusif sehingga murid antusias untuk belajar.

3. Ada pengaruh kompetensi sosial guru terhadap interaksi belajar mengajar di SMP Negeri 1 Gunungguruh kota Sukabumi, dengan perolehan skor koefisien $\mathrm{F}$ sebesar 123,306 dan P-value 0,000 yang lebih kecil dari $\alpha=$ 0,025 . Hal ini berarti ada pengaruh yang signifikan antara variabel X (kompetensi sosial guru) terhadap variabel $\mathrm{Y}$ (interaksi belajar mengajar) di SMP Negeri 1 Gunungguruh kota Sukabumi. Sekitar 90,5\% dari variansi interaksi belajar mengajar dapat dijelaskan melalui kompetensi sosial guru dalam bentuk persamaan regresi $\hat{Y}=-1,268+$ $0,951 X$.

\section{Implikasi}

Walaupun kegiatan interaksi belajar mengajar di kelas tidak hanya dipengaruhi oleh kompetensi sosial guru akan tetapi kompetensi sosial guru sangat penting dalam menjalin hubungan baik dengan murid, sesama guru, tenaga kependidikan, kepala sekolah dan masyarakat sehingga tercapai hubungan yang harmonis. Oleh karena itu, diharapkan para guru mengembangkan kompetensi sosial yang dimilikinya. Adapun yang dapat dilakukan oleh sekolah ialah dengan memberikan motivasi kepada para guru agar terus mengembangkan kompetensi sosial yang dimiliki, dan terus meningkatkan pengelolaan kelasnya agar interaksi belajar mengajar yang kondusif dapat tercapai sehingga mampu meningkatkan prestasi belajar murid.

\section{DAFTAR PUSTAKA}

Afifah N. 2012. Interaksi belajar matematika siswa dalam pembelajaran kooperatif tipe STAD. Jurnal Pedagogia. 1 (2): 145-152.

Ashsiddiqi M. 2012. Kompetensi sosial guru dalam pembelajaran dan pengembangannya. Jurnal Ta'dib 17(1): 61-67.

PP Republik Indonesia No. 74 Tahun 2008 tentang Guru.

Suryosubroto. 2009. Proses belajar mengajar di sekolah. Cetakan Pertama. Rineka Cipta, Jakarta.

Yamin M. 2013. Kiat membelajarkan siswa. Cetakan Pertama. GP Press Group, Jakarta. 